\title{
Socialism in the Neoliberal Age: Debates and Arguments ${ }^{1}$
}

DOI: $10.26466 /$ opus.869029

\author{
$*$ \\ Bedir Sala* \\ * Dr. Afyon Kocatepe University, Department of Sociology, Afyonkarahisar/Turkey \\ E-Mail: bedirsala@aku.edu.tr \\ ORCID: $\underline{0000-0002-6892-2664}$
}

\begin{abstract}
The neoliberal period consists of the application of a series of restructuring policies, including rapid change of economy, politics, culture, and social environment. Socialist movements are at the forefront of the opposition to neoliberal policies, which have been applied in many countries after 1980 and almost all over the world in the 2000s. Marxism was marginalized and in crisis in this period on the counter of neoliberalism. Intra-Marxist discussions also led to the emergence of new arguments and different interpretations. This study will try to create a theoretical framework about which issues stand out and the orientation of socialism through focusing on intra-Marxist discussions. The approaches and distinctions of reductionism and class analysis among theoretical debates will be emphasized, and how these fundamental issues were discussed by Marxists in the neoliberal period will be examined. Another important issue is the different Marxist interpretations that have been formed as a result of new arguments. In this regard, what the issues that constitute the agenda of trends such as the new left and the radical left are and in what context they will be discussed will be examined.
\end{abstract}

Anahtar Kelimeler: Neoliberalism, Socialism, Social Class, the New Left, the Radical Left.

\footnotetext{
${ }^{1}$ This article was produced as a part of PhD thesis entitled "The Justice and Development Party in the Discourse of the Socialist Opposition in Turkey" (2016) at Institute of Social Sciences, Selçuk University, Konya, Turkey.
} 


\section{Neoliberal Çağda Sosyalizm: Tartışmalar ve Arayışlar}

\section{Öz}

Ekonomi, siyaset, kültür ve toplumsal alanın hızlı bir şekilde değiştiği neoliebral dönem bir dizi yeniden yapılanma politikalarının uygulanmasından oluşuyor. 1980 sonrasinda birçok ülkede ve 2000'lerde ise neredeyse tüm dünyada uygulama alanı bulan neoliberal politikalara yönelik karşıt hareketlerin başında ise sosyalist hareketler gelmektedir. Ancak bu dönem aynı zamanda Ortodoks Marksizm'in kuramsal

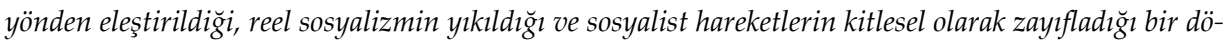
nem olmuştur. Neoliberalizm karşısında Marksizm'in marjinalleştiği ve krize girdiği bu dönemde Marksist içi tartışmalar aynı zamanda yeni arayışların ve farklı yorumları ortaya çıkmasına yol açmıştır. Bu çalışma Marksist içi tartışmalara odaklanarak, hangi konuların öne çıktığını ve sosyalizmin yönelimi hakkında teorik bir çerçeve oluşturmaya çalışacaktır. Teorik tartışmalardan indirgemecilik ve sinıf analizine ilişkin yaklaşımlar ve ayrımlar üzerinde durularak bu temel konuların neoliberal dönemde Marksistler tarafindan nasıl tartışıldı̆̆̆ incelenecektir. Bir diğer önemli konu da yeni arayışlar sonucunda şekillenen farklı Marksist yorumlardır. Ayrıca yeni sol ve radikal sol gibi eğilimlerin gündemini oluşturan konuların neler olduğu ve hangi bağlamda tartışıldı̆̆ı incelenecektir.

Anahtar kelimeler: Neoliberalizm, Sosyalizm, Toplumsal Sinf, Yeni Sol, Radikal Sol. 


\section{Introduction}

Neoliberalism is an economic model that includes marketization of free investment, privatization and public funding in order to remove all obstacles to private capital. The concept of neoliberalism used to characterize a set of economic regulations packages refers to the current form of capitalism for Marxists (Peters, 2001; Berlin, 1996, p.193-204). Also, Marxist analysts associate globalization with neoliberalism. The phenomenon of globalization is accepted as a result of neoliberalism (Harris, 2000). Accordingly, globalization causes new social inequalities due to its composed regulation. Upon this regulation, developing countries' state support for social service areas such as health and education has been decreased (Deacon, 2011, p.109). Mainly privatizations constitute the central tendency of neoliberal economic policies. Because the primary purpose of neoliberal policies is to leave employment to private capital instead of the state. Hence, the International Monetary Fund and the World Bank prepared privatization programs for developing countries after 1980. Privatizations are based on the grounds that the international market will liberalize, productivity will increase and capital will spread to the base, public. Therefore, the social state has been weakened because of privatization policies (Şenkal, 2011, p.507-509; Robinson and Harris 2000, p.43).

Marxists qualified these applied economic policies as the renewal of the capitalist system itself. There are also those ones who define the period starting with the end of the $20^{\text {th }}$ century and including today as "neoliberal market civilization" (Gill, 1995). The socialist countries have integrated into the capitalist world-system through applying neoliberal economic policies upon entering into a crisis of the statist economic model used in socialist countries in this period. Thus, neoliberalism was spread as an "unrivaled" model towards the 1990s. The period when neoliberalism was strengthened was the period when Marxism was also marginalized according to those ones who define neoliberalism as "the most successful ideology of history," which has not encountered any serious opposition in the West for the first time and the world since the reform (Callinicos, 2005, p. 25). 
Neoliberalism does not include only economic regulation. The political and social spheres were shaped together with the economy and also socialist movements and parties lost their power in this period. The weakening of socialism both at the level of thought and at the level of action brought many discussions along with it. On the other hand, the criticism of poststructuralist and post-modernist approaches to modernism and grand theories played an important role in the marginalization of Marxism. The common point of these approaches is to start a discussion around new concepts such as the new state of capitalism, consumer society, the irrational tendency of the individual, pluralism and multiculturalism through problematizing modernism. Marxism was influenced from enlightenment philosophy and so it carries the basic characteristic of modernism. Accordingly, it has received its share of criticisms of modernism. In addition, the basic foundations of Marxist politics, such as the subject-structure relationship and the revolutionary role attributed to the labor force, have also been problematized.

Socialists entered government in many countries in the $20^{\text {th }}$ century, especially in Russia. Thus, a socialist bloc emerged against the capitalist bloc under the leadership of the Soviet Union after the Second World War. Anymore, socialists have the opportunity to realize ideals such as the rule of the labor force as a hegemonic force determining international political balances, a new form of social organization, and the construction of a socialist order alternative to the capitalist system. The communist parties were engaged in an active political struggle within close relations with the Soviets in the countries where the socialists were not in power. However, at the beginning of the 1980s, the economic model implemented by the Soviet Union regressed against the liberal economy. This situation caused unrest in many socialist countries and increased social reactions towards the socialist system, especially in Eastern European countries. In this case, the blockage of the system, the Soviet Union applied the policies of "glasnost" and "perestroika" under the leadership of Mikhail Gorbachev in 1985. However, these policies could not prevent the dissolution of the socialist bloc and the Soviet Union, which started to dissolve due to the blockage of the system in 1991. 
Real socialism has been an important experience for socialists. However, besides this experience, the collapse of real socialism meant the defeat of the socialists. This defeat led to the disintegration of communist parties, which were strongly organized in many countries, and the weakening of the socialist movement's influence on the masses. Socialist politics has entered into a period of withdrawal against to both the collapse of real socialism and post-modernist and poststructuralist currents. It is possible to read this process as a "self-criticism" and renewal process for the left. Also, there has been a period of depression in which the left has weakened and lost its self-confidence, which was subjected to similar accusations that the left thought and politics "did not match the facts" or "lagged behind reality" (Laçiner, 2000, p.27). This study aims to create a general framework about the pursuit and orientation of socialists by focusing on the internal discussions about socialism in this depressing period.

\section{Theoretical Debates: Economic Reductionism and Social Classes}

As a theory of social analysis, Marxism claims that it shapes social relations and social institutions of the economy as its substructure, in general terms. This approach, which causes to define Marxism as a reductionist social theory, is also used as a strong argument in criticisms of Marxism. In addition, Marx's attempt to explain historical processes with a dialectical materialist method and presenting this method in a scientific framework supports the criticisms that Marxism is reductionist. The clearest place where Marx's reductionist approach is seen is Marx's views that material life determines social, political and intellectual life in his criticism of Hegelian philosophy (Marx, 1979, p.25).

Marx's criticism of Hegel's idealist philosophy constitutes the basic model of his theory for Marxists. Most Marxists or non-Marxists define Marxist theory in this context. This model constitutes the weakest point of Marxist theory. Because if social facts do not fit this model, then the weakness and inadequacy of the model will emerge. On the other hand, some Marxists claim that the Marxist theory is not solely this model. The concepts composing this model are only the conceptualizations of certain phenomena. 
Franz Jakubowski (Füredi, 2001, p.226) defends that concepts such as infrastructure, superstructure are the accessed results of Marxist theory, not the theory itself, against those who see Marxist theory as solely this model. British Marxist Edward P. Thompson, who put a critical distance to the approach that the superstructure determines the superstructure does not affect the infrastructure in any way, emphasizes that the superstructure can also affect the infrastructure and states that the political context is also important in shaping the consciousness of the labor force (Blackledge, 2014, p.260). The views of Jakubowski and Thompson are like a response to the Marxists who squeeze Marxism into the infrastructuresuperstructure model and to those who criticize Marxism with reductionism over this model. Post-Marxists, who interpret the basic concepts of Marxism differently and defend that the labor force has become insignificant through describing the concept of class, one of the basic concepts of Marxism, as "essentialist" (Laclau and Mouffe, 2001; Geras, 1987, p.50-51), they also considered the policy as an important factor through redefining the economy (Adakl1, 2001, p.13-14).

Althusser's evaluations reinterpreting Marxism and questioning the relationship between economy and politics have become important references for Post-Marxists. According to Althusser, the infrastructure was not more determinant than superstructures such as economy, politics and ideology (Althusser, 2003; Resnick and Wolff, 1987, p.81-95; 2006, p.39-48). This thesis of Althusser denying the determination of the economy has opened the door to discussions that highlight political and cultural elements and emphasizing the priority of political struggle. According to the Post-Marxists that emerged from these discussions, the failure of state capitalism executed by Stalin was accepted as the defeat of real socialism, while the dissolution of the labor force showed that traditional Marxism, which attributes revolutionary meaning to the labor force has archaized. Therefore, Post-Marxism, which alleged for the failure of real socialism and the obsolescence of traditional Marxist theory, tended towards a different political strategy. This strategy was based on carrying out a radical struggle away from violence, democratically, and to form an anti-capitalist hegemonic bloc at the global level, thanks to the formulation of Laclau and Mouffe (2001). 
Intra-Marxist debates around reductionism were briefly mentioned above. In fact, similar discussions are continuing in the Turkish Left. The post-Marxist tendency becoming significant majorly in the year 1990 in Turkish Left emphasized that revolutionary role which was loaded to class movement by the socialist movement act was exaggerated, the class fashion got behind, civil socialism and mass democracy became forefront, socialism standing close to political equality claims of different ethnic and religious identities. This trend was labeled as "liberal left" and was defined as a "deviation" from Marxism and "bourgeois democracy" by other socialist movements.

One of the most important issues discussed in relation to economic reductionism is the concept of "class." Social and political analyses in Marxism are implemented in the context of the class. Social class, one of the basic concepts of Marxist thought, is used as an analytical concept that explains and makes sense of the interrelated layers of this regulation. Accordingly, society consists of a class distinction basically. The emergence of this class distinction has developed in parallel with the emergence of private property. This situation is not special to a particular society. It is a qualitative condition that exists in all societies where private property arose. In brief, the class separation and conflict that arise in parallel with private property in Marxist thought is a theoretical approach that explains the structuring of social regulation.

The concept of social class, which became popular again in the $18^{\text {th }}$ century, turned into one of the dominant concepts of social sciences upon the theoretical approach of Karl Marx. Marx contributed to the concept of social class in three aspects. These are: the class struggle of all history is historical, a class in itself does not have to be a class for itself, and that the main conflict of capitalist society takes place between those who have the means of production and those who do not (Wallerstein, 2000, p.145). According to Marx, social regulations are products of historical processes. History is an inter-class struggle rather than an impersonal process led through goals that people cannot comprehend. There is an irreconcilable contradiction between the class that owns the means of production and the class that makes a living on its labor.

In addition to the transformation of the labor force, the new middleclass theory discussed in the middle of the twentieth century has become 
an argument that undermines the absolute conflict thesis between the labor force and the bourgeoisie established by Orthodox Marxism. Classical Marxist class analyses included the prediction that capitalist society has been basically composed of two classes, and the other rest of the social sections would eventually disappear. These social sections, which were described as new middle classes and were not expected for Orthodox Marxism, consist of those labor forces in the service sector of developed countries. On the other hand, there is a common approach that the labor force transforms into middle classes

over time, adopts lifestyles of the middle class, and the majority of the population forms a homogeneous section living at a certain welfare level (Yanıklar, 2010, p.215). Therefore, approaches to the new middle class indicate that the previous class analyses are no longer valid, and the role of classes in social change is diminishing.

The most distinctive feature of this class, which is described as the new middle class, is its being "consumer class" as emphasized by Kharas (2010, p.10). This new middle-class remains an ambiguous class for Marxist class analysts because of not having the means of production and being different from the labor force in terms of living standards. Therefore, it is mostly analyzed in the context of Weberian class theory (Yildırım, 2012, p.74).

Undoubtedly, there was an emphasis on the intermediate class, corresponding to the middle-class in Marx's class analysis. However, Marxist analysts considered this stratum as an intermediate class between the bourgeoisie and the proletariat. Since this intermediate class could not break out of the antagonism between the bourgeoisie and the proletariat, so it would weaken against capital and joined the proletariat. However, upon the growth and development of the middle-classes, which have been described as intermediate classes, the approach of socialist politics on this issue has also changed. The Marxists, who considered the middle classes as the social foundation of fascist movements in the early period, accordingly began to allege that forwarding to socialism could be possible with the alliance with the labor force and the middle classes. In the 1970s, the communist parties of Europe have been expressing the necessity of addressing the new middle class and establishing new alliances for political success (Bottomore, 1991, p.180). 
The concept of new social movements is used for movements that emerged independently of class relations and class identities of social movements upon becoming outdated of the old social movements, the labor force movement. However, Alain Touraine uses the concept of new social movements for the movements in the post-industrial society that emerged together with the new power relations and new relationship form (Çayır, 1999, p.16). Touraine (1999, p.51) opposes the separation of a social movement from a class phenomenon; he states that the difference between social movement and class is the definition of class as a "situation," whereas social movements are the "action of an actor questioning historicity."

Although Touraine does not acknowledge a distinct difference between social movements and class, most analyses about the subject in social sciences evaluate new social movements independently of class relations. Most of the studies on this subject do not even mention the class. Because it can be very difficult to determine the nature of the class of these movements that sometimes emerge as an environmental movement, a feminist movement, a student movement, or an anti-war movement. On the other hand, new social movements replace class-based social movements with identities such as ethnicity and gender.

\section{Arguments: From the New Left to the Radical Left}

American political scientist Francis Fukuyama caused a new discussion due to his published work, "The End of History and the Last Man" including the theses in 1992. Fukuyama (2006) claims that the ideologies of socialism and fascism that he positioned against liberalism have ended, that liberalism has survived in the ideological struggle, and that history has ended with the best system, liberal democracy. Fukuyama, who claims that humanity finds its ideal order in liberalism, closes history by predicting that no political power will emerge anymore and that liberal values will become universal. Socialism lost its political power and theoretical weight in this period, but Latin socialism, which started to rise in the late 1990s, caused the despaired socialist movements to revive and gain confidence again. Socialist movements, which focus not only on the labor force 
but also on other areas of social struggle, continue their existence both in the social and political spheres in many countries today.

This assertive thesis of Fukuyama becomes controversial when the successive crises of liberalism are considered. Upon the global crisis of liberal economy in 2008, the unemployment rate increased in many European countries. Countries like Spain, Italy, and Greece were almost bankrupt. On the other hand, the increase in discriminatory policies towards foreigners, such as Islamophobia in the West shows that liberal democracy is also in crisis. The widening of the social base of the left parties with the effect of the crises experienced by the liberal world in both the economic and political fields is seen in the election results in the 2000s. When the election results in Europe after 2008 are considered, the Socialist Party candidate became the president after 17 years in France, while the Labor Party in Britain was getting the highest vote in general and local elections. Except this, leftist parties came the power in many European countries such as Portugal, Norway, Denmark, Romania, and Greece. However, leftist parties in these countries did not come to power due to the politicization and organization of the labor force. Rather, they were parties that had the support of the petty-bourgeois class. In general, the distinctive feature of the leftist parties engaged in internal politics is their having a discourse that includes the petty bourgeoisie as well as the labor force.

Latin America is one of the regions where the left has arisen. In the early 2000s, parties that defined themselves as socialist became to power one after another in Latin America. The dominant discourse of the Latin American Left is opposition to America's hegemony in the region. In addition, "The most common feature of left orientations in Latin America is their emphasis on social participation. Their preference for radical democracy over liberal democracy and their emphasis on a new unity through defending national symbols are among the other important headings of the common features they share" (Özuğurlu, 2012, p.15). The cultural indigenization of the left composes the main factor in the massification of left politics as seen in the Latin American Left. Different interpretations, such as the new left and the radical left that emerged as a result of new arguments have an important role in the massification of the left.

The concept of the new left appears as an alternative left movement and interpretation attempt of the European Left against the real socialism 
led by the Soviets and Orthodox Marxism after the Second World War. The new left contains many different discussions within itself. However, the reason why these discussions are described as the new left is that it's manifesting as separating from traditional Marxism. Basically, it emphasizes the society-state contradiction rather than the labor-capital contradiction of traditional Marxism. There is a heavy emphasis on inequality in society, but it does not reduce this inequality to the labor-capital conflict.

The new left defended a non-dogmatic interpretation of Marxism, based on the qualitative change of capitalism and the labor force. As capitalism has changed, the masses could not influence the political system anymore through democratic means. The Labor Force had many things to lose. As it was emphasized by Herbert Marcuse (1979, p.3), one of the important theorists of the new left movement of the 1970s with his interest in politics and social struggle compared to other Frankfurt School members, the dimensions of this new change were not only economic and political change but different modes of production and new institutions. On the other hand, the traditional left criticized the new left parties, claiming that those parties lacked a mass base and became far from the labor force.

The main issue where the new left breaks from traditional Marxism was class analysis. In the post-1980 period, class analyses around the world were described as reductionist and so they lost their reputation (Öğütle, 2014, p.7). One of the reasons why class analysis has been discredited, lost reputation was the change of the society that has undergone from the classical industrial society to the advanced industrial society. Society was no longer a society in which capitalism continuing its crude hegemony as Marx and Lenin conceptualized. From this point of view, Marxists such as Herbert Marcuse, Raymond Williams, and Stuart Hall broke off from the social analyses of classical Marxism and turned to different analyses.

One of the political movements influenced by new left thought is the so-called "third-way" movement represented by the British Labor Party. Its theorist is the British sociologist Anthony Giddens. The idea of the third way arose with the claim of being an alternative to capitalism and socialism. Giddens (1998) expresses this situation as "beyond of the right and the left". The idea of the third way is in a political seek beyond both 
the right and the left, but it also cares about Marxist values. It is an idea that emphasizes mostly the humanist side of Marxism.

The third way considers ideological systems as obsolete, rather than creating a new ideological system - has been in an effort to produce solutions within the existing system and to get their support by taking into account the demands of the constituency. Some of the distinguishing features of the third way thought are as follows: the belief that "top-down" state socialism is now dead; emphasis on community and moral responsibility; socialism's accepting the idea of reconciliation in society rather than conflict in society; replacing traditional socialism's commitment to equality with social inclusion; neoliberals' defending of the competitive market state rather than the idea of the state as a balance against capitalism by the minimal state and social democrats (Heywood, 2013, p.154-157).

The radical left against the new left, which criticizes traditional Marxism especially based on the argument that a new social order exists, claims that this new social regulation is only a formal change of capitalism and that capitalism has not undergone any qualitative change. Fredric Jameson's approach to this new social order in particular post-modernism is also the common approach of the radical left. Jameson (2011, p.13) argues that post-modernism is not the cultural dominance of a new order called post-industrial society. It is merely a reflection of another transformation that capitalism has undergone.

In the neoliberal era, socialism ceased being an ideology against absolute capitalism and entered different orientations. Identity politics was prime among those orientations (Bauman, 2002, p.471-482). The new left sought a policy against oppression on different identities rather than merely criticizing absolute capitalism and class conflict in capitalist society. It was insensitive to identities such as traditional left ethnic, gender, etc. While the class division was being taken as a basis, other social divisions were either ignored or considered secondary. However, in the neoliberal era, when the left was weakened and the civilian sphere came to the fore against the state, some of the identity-based social movements expressed themselves in a leftist discourse. The class conflict has left its place to identity struggle. In addition to identities such as ethnicity, language, gender, environmental protection, animal rights, etc., social movements 
began to constitute the new agenda of leftist politics. Therefore, organizations that are smaller and often focusing on the concerns of the petty bourgeoisie can shape left politics.

Today, there are not only class inequalities such as poverty and unequal development, but also problems such as discrimination and exclusion that cause human tragedies. On the one hand, there is the unfair distribution of income and wealth among social sections; on the other hand, there are marginalizing problems such as the inability of people with different cultural identities to benefit from equal rights or exclusion (Keyman, 2008, p.216). This situation causes social displeasure and social reactions. Social responses are transformed into social movements by organizing apart from the class context. Some socialist movements, especially those who share the approach that the labor force is outdated, integrate with these social movements, expanding the scope of socialist politics and publicizing socialism by reinterpreting it out of the class analysis.

The theorists such as Jurgen Habermas and Alain Touraine, who come from the leftist tradition, have contributed to the replacement of the labor force by new social movements that make cultural identity forefront (Lee, 2007). There is a claim that new social movements emerged in the society described as post-industrial by these theorists and that the proletariat class lost its revolutionary subject and integrated into capitalism (Fuat, 2014, p.19). At the end of the theoretical approaches of Marxist theorists affirming new social movements and social demands far from class dynamics, it was seen that socialist movements have turned towards different social movements and in some countries, socialist movements have almost removed the labor force from the agenda and turned towards identity politics in the post-1990 period.

The globalization phenomenon, which improves transportation and communication, integrates and converges the world economically, politically and culturally, also constitutes an important place for the left. Especially how to define globalization and the nature of the relationship between globalization and capitalism are the main topics of discussion on this matter. The basic approach to globalization for socialist thought is the thesis that "globalization is a new stage of imperialism" (Timur, 2002, p.213). 
Antonio Negri and Michael Hard stand out among the most important socialist theorists who approach critically to globalization. These theorists claim that the era of nation-states is over upon the globalization of capital through crossing national borders easily without encountering any obstacle and that a decentralized and landless market that seizes the world has introduced a new mode of domination. The theorists who call this mode of domination as "Empire" explain the concept as follows:

"The concept of Empire is characterized fundamentally by a lack of boundaries: Empire's rule has no limits. First and foremost, then, the concept of Empire posits a regime that effectively encompasses the spatial totality, or really that rules over the entire 'civilized' world. No territorial boundaries limit its reign" (Negri and Hard, 2000, p.XIV).

The theorists alleged that imperialism has ended and the imperial period has begun on the basis of post-industrial social theories. This work of Hardt and Negri is considered the most radical theoretical text of antiglobalization socialism.

Unlike the traditional left, one of the issues on which the new left thought emphasized was the urban and space analysis led by Henri Lefebvre and David Harvey. Lefebvre and Harvey initiated a discussion within the left, mostly with the interpretation of "geographical materialism," caused to a reinterpretation of the concept of space in a Marxist framework. The concept of space was generally designed in Marxist analysis to serve the interests of the bourgeoisie and to maintain the privilege of the bourgeoisie.

Lefebvre considered space as social production and argued that space production practices should not be considered as only physical, but also the daily interactions of people. Space is an economic and social outcome for Lefebvre and also space is not neutral. Harvey, another Marxist theorist on space, discussed space and urbanism in the context of industrial capitalism. He tried to reveal the decisiveness of space on the social sphere by analyzing the conflict between social mobility and the formal structure of space. Harvey, who explained his fundamental approach about space in his work titled "Social Justice and the City" (2009, p.310), expressed how space was constructed ideologically as follows: 
"We have already acknowledged that the organization of space can reflect and affect social relationships. But created space has a deeper meaning than just that. In the ancient city, the organization of space was a symbolic re-creation of a supposed cosmic order. It had an ideological purpose. Created space in the modern city has an equivalent ideological purpose. In part, it reflects the prevailing ideology of the ruling groups and institutions in society. In part, it is fashioned by the dynamics of market forces which can easily produce results that nobody in particular wants. Created space is an "ethnic domain" in only a very limited sense. Yet created space is an integral part of an intricate sign-process that gives direction and meaning to daily life within the urban culture."

The views of Lefebvre and Harvey provided important theoretical contributions to the left in the period after 1980 when the urban and environmental struggles were the carrier of socialist opposition. The leading leftist groups that came to the fore in social movements and actions are defined as radical or ultra-leftist groups in the 2000s. Radical leftist groups are deprived of the quantitative power that can come to power through democratic means, but they can force the governments with their opposition actions in the civilian arena and protests on various issues. Radical leftist groups present solutions at a fully solidaristic and egalitarian level through opposing many social discriminations produced by the capitalist system against both the traditional left and the liberal left. This leftist approach advocating radical democracy criticizes the compromising politics of both the new left and the liberal left with bourgeois democracy.

Ernesto Laclau and Chantal Mouffe (2001), who established intimacy to radical democracy and the left, defend the radical democracy thesis for socialist strategy against neoliberal hegemony. Radical democracy focuses mainly on identity differences. Despite the fact that identity difference turns into a cause of conflict, it advocates the construction of a public environment that can recognize these differences mutually and can be represented without any obstacle. The socialists who regarded the class struggle as insufficient and paid attention to the identity struggle turned to the radical democratic theory in the post-Soviet period. 


\section{Conclusion}

The fundamental social services such as health and education were tried to be rearranged in a way that everyone could reach equally in countries where socialism was in power in the $20^{\text {th }}$ century. The foreign capital control over natural resources was eliminated and expropriation was adopted. The policies aiming for equal life standards and distribution of wealth were tried to be applied. However, even though other socialist countries, primarily the Soviets, advocated a classless society, they could not prevent the emergence of new classes. Ultimately, socialism was dissolved through suffering similar structural crises.

The change in the social and economic order after the Second World War revealed the theoretical inadequacy of Marxism. Therefore, Orthodox Marxist class analysis lost its importance as workers' working conditions changed and they gained new rights and adopted a more prosperous lifestyle. The capitalist system abolished the revolutionary transformation force expected from the labor force through including the labor force in the system and adopting it with reforms.

All these developments led to an increase in theoretical debates and new arguments in socialist movements. The new arguments on the left, starting with the new left and reaching different interpretations, such as the radical left, also changed the agenda of the socialist movements. The outstanding trend due to the new arguments emphasized that the revolutionary role the socialist movement attributed to the class movement was exaggerated, that class fashion was left behind, that civil socialism and mass democracy were emphasized, and socialism that stood close to the demands of different ethnic and religious identities for political equality.

\section{Refenceces}

Adaklı, G. (2001). Post-Marksizmin kuramsal ve siyasal açmazları. Praksis, 1, 13-32.

Althusser, L. (2014). On the reproduction of capitalism: Ideology and ideological state apparatuses (translated by G. M. Goshgarian). New York: Verso Books. 
Bauman, Z. (2002). Identity in the globalizing world. Eliézer Ben Rafael and Yitzhak Sternberg (Ed), Identity, Culture and Globalization. Leiden: International Institute of Sociology.

Berlin, J. (1996). Contemporary rhetoric and late capitalism: Culture as an imperializing force. Chronis Polychroniou ve Harry R. Targ (Ed), Marxism Today: Essays on Capitalism, Socialism, and Strategies for Social Change. Connecticut: Praeger Publishers.

Blackledge, P. (2014). Siyasal Marksizm. Jacques Bidet and Stathis Kouvelakis (Ed), Çă̆daş Marksizm İçin Eleştirel Kılavuz. İstanbul: Yordam Kitap.

Bottomore, T. (1991). A dictionary of Marxist thought. Massachusetts: Blackwell Publishers.

Callinicos, A. (2005). Anglo-Sakson Marksizminin ana hatları (translated by Erkal Ünal and Burak Gürel). Praksis, 13, 15-32.

Çayır, K. (1999). Toplumsal sahnenin yeni aktörleri: Yeni sosyal hareketler. Kenan Çayır (Ed), Yeni Sosyal Hareketler. İstanbul: Kaknüs Yayınları.

Deacon, B. (2011). Küreselleşme ve sosyal politika: Hakkaniyetli bir refaha tehdit. Ayşe Buğra and Çağlar Keyder (Ed), Sosyal Politika Yazıları. İstanbul: İletişim Yayınları.

Fuat, S. (2014). Yeni toplumsal sorunları kim, nasıl çözecek?. Marksist Tutum, 106.

Fukuyama, F. (2006). The end of history and the last man. New York: Free Press.

Füredi, F. (2001). Tarihsel materyalizmde ideoloji ve üstyapı'ya önsüz. (translated by İbrahim Y1ld1z). Praksis, 1, 224-46.

Geras, N. (1987). Post-Marxism? New Left Review, I(163), 42-82.

Giddens, A. (1998). The third way: The renewal of social democracy. Cambridge: Polity Press.

Gill, S. (1995). Globalization, market civilization and disciplinary neoliberalism. Journal of International Studies, 24(3), 399-423.

Harris, R. L. (2000). The Effects of Globalization and Neoliberalism in Latin America at the beginning of the millennium. Journal of Developing Societies, 16(1), 139-162.

Harvey, D. (2009). Social justice and the city. Athens: the University of Georgia Press.

Heywood, A. (2013). Siyasî ideolojiler: Bir Giriş (translated by Ahmet Kemal Bayram and Özgür Tüfekçi). Ankara: Adres Yayınları.

Jameson, F. (2011). Postmodernizm ya da Geç Kapitalizmin kültürel mantı̆̆ı (translated by Nuri Plümer and Abdülkadir Gölcü). Ankara: Nirengi Kitap. 
Keyman, F. (2008). Solun Yeni ve Ayrıştırıcı Dili. Toplum ve Demokrasi, 2(2), 215-218.

Kharas, H. (2010). The emerging Middle class in developing countries. OECD Development Centre Working Paper, No. 285.

Laclau, E.; Chantal, M. (2001). Hegemony and socialist strategy: Towards a radical democratic politics.Londra: Verso.

Laçiner, Ö. (2000). Eşitlik ve özgürlüğün sentezi olarak Sosyalizm. Tanıl Bora (Ed), Yeni Bir Sol Tahayyül İçin. İstanbul: Birikim Yayınları.

Lee, S. H. (2007). Debating new social movements: Culture, identity, and social fragmentation. Lanham: University Press of America.

Marcuse, H. (1979). The failure of the new left?. New German Critique, 18, 3-11.

Marx, K. (1979). Ekonomi politiğin eleştirisine katkı (translated by Sevim Belli). İstanbul: Sol Yayınları.

Negri, A. and Hardt, M. (2000). Empire. Massachusetts: Harvard University Press.

Öğütle, V. S. (2014). Önsüz. Erik Olin Wright (Ed) Sınıf Analizine Yaklaşımlar. Ankara: NotaBene Yayınları.

Özuğurlu, S. B. (2012). Latin Amerika'da solun yükselişinin siyasal sisteme etkileri. Mülkiye Dergisi, 36, 1-274.

Peters, M. A. (2001). Poststructuralism, Marxism, and Neoliberalism: Between theory and politics. Boston: Rowman \& Littlefield Publishers.

Robinson, W. I. and Harris, J. (2000). Towards a global ruling class? Globalization and the transnational Capitalist Class. Science $\mathcal{E}$ Society, 64(1), 11-54.

Resnick, S. A. and Wolff, R. D. (1987). Knowledge and class: A marxian critique of political economy. Chicago: the University of Chicago Press.

Şenkal, A.(2011). Küreselleşme sürecinde sosyal politika. İstanbul: Alfa Yayınları.

Timur, T. (2002). Küreselleşme'den 'İmparatorluk'a 11 Eylül: Dönüm noktası mi? Praksis, 7, 213-224.

Touraine, A. (1999). Toplumdan toplumsal harekete. Kenan Çayır (Ed), Yeni Sosyal Hareketler. İstanbul: Kaknüs Yayınları.

Yanıklar, C. (2010). Postmodernist antipati: Postmodernist sinıf(sızlık) yaklaşımlarına eleştirel bir bakış. Ankara Üniversitesi SBF Dergisi, 65(1), 205-227.

Yıldırım, C. (2012). Orta sınıfa iktisadi yaklaşım. Girişimcilik ve Kalkınma Dergisi, 7(1), 69-86. 
Wallerstein, I. (2000). Kapitalist dünya ekonomisinde sınıf çatışması. Etienne Balibar and Immanuel Wallerstein (Ed), Irk, Sinff, Ulus, (translated by Nazlı Ökten). İstanbul: Metis Yayınları.

\section{Citation Information}

Sala, B. (2021). Socialism in the neoliberal age: Debates and arguments. OPUS-International Journal of Society Studies, 18(42), 5762-5780. DOI: 10.26466/opus. 869029. 